\title{
Hunctus rex. El imaginario de la unción de los reyes en la España de los siglos $\mathrm{VI}$ al $\mathrm{XI}^{1}$
}

Isidro G. BANGO TORVISO

\section{Resumen}

En este breve estudio se aborda el origen, significado y práctica de la consagración del Rey de España de los siglos VI al XI. Además, utilizando las fuentes documentales y las imágenes plásticas, se propone la recreación de la ceremonia de la coronación e imposición de los regalia.

Palabras Clave: Realeza, España, siglos VI-XI, coronación.

\section{Summary}

This brief study deals with the origin, meaning and practice of the consecration of the King in the Spain of the 6th to the 11th centuries. In addition, using documentary source and plastic images, it is proposed the recreation of the Coronation ceremony and the imposition of the regalia.

Keywords: Royalty, Spain, 6th to 10th centuries A.D. coronation.

En la España del siglo VI la minoría goda gobernante y la hispanorromana gobernada se enfrentaron con uno de los temas más fascinantes de una sociedad que necesita dar forma a la organización politicoadministrativa que les gobierne, prácticamente la creación de la teoría política de un estado. La caída de Roma y la lejanía de Bizancio, la nueva capital de todo el imperio romano, dejaban a Hispania bajo el gobierno efectivo de los visigodos. La cultura tardoantigua que supervivía en la Hispania de esta centuria es

1 Deseo que este modesto trabajo sea un homenaje a Manuel Bendala, cuyas obras siempre me han permitido ver que las creaciones del pasado que conservamos son mucho más que tan importante que permite teorizar sobre el tema con excelentes fundamentos jurídicos de la más pura y estricta tradición romana. Sin embargo no es este el tema que nos interesa aquí, sino uno referente a la definición de la figura regia por los padres de la iglesia hispana no siguiendo las prácticas romanas, sino las de los viejos usos de la monarquía hebrea recogida en el Antiguo Testamento. Se formó así un proceso en la "creación de un rey" que contaba con tres fases bien definidas: la elección, la unción/consagración y la

formas, pues constituyen un imaginario de la vida de quienes las hicieron realidad. 
coronación. El sistema electivo tenía su origen en la cultura visigoda tradicional y terminará siendo mediatizado por la incursión de los obispos en el colegio electoral. El elegido así es un jefe que no deja de ser a su manera un primus inter pares. Contaría con algún elemento que lo señalase entre el conjunto de sus gentes, pero no un aparato emblemático y protocolario de gran trascendencia. En el proceso de configuración de la imagen de un rey pronto adoptaría signos propios de la dignidad imperial romana. Entonces sí, ya se distinguía por su aspecto claramente de los que eran sus iguales. Pero seguía faltando algo más profundo, el aspecto religioso; entendido este concepto en su sentido más primario, lo que une al hombre con Dios. Es aquello que, como veremos más adelante, le permitirá decir: Después del Dios del cielo, el que manda soy yo. De la estrecha relación entre la aristocracia goda y la iglesia hispana surgirá la solución. Será la unción, por ella el monarca contará con una doble personalidad: una humana y otra sagrada ${ }^{2}$. Argumentación del fundamento y fórmula del ritual tienen en la época hispanogoda su origen más antiguo conocido y practicado, pasando después a otros reinos, especialmente el franco ${ }^{3}$. Una vez convertida la persona en sagrada se le entregarán las insignias de su nueva condición. Esta tercera parte también será ejecutada por el clero, pero su desarrollo en España seguirá un proceso distinto al del mundo

2 Se trata de la teoría de los dos cuerpos del rey que desarrolló Cantorowicz a partir del tratado De Consecratione pontificum et regum, obra del conocido como Anónimo de York (Siglo XI): "Debemos reconocer por tanto en el rey una persona geminada, una proveniente de la naturaleza geminada, y otra de la gracia. Una por la cual, en virtud de la naturaleza, se asemejaba a los hombres; y otra por la cual, en virtud de la eminencia de la deificación y por el poder del sacramento [de la consagración] superaba a todos los demás" (Cantorowicz, p. 32).

3 Es opinión reciente el señalar la poca preocupación que tuvo la monarquía franca por una práctica litúrgica en la que la institución o los propios reyes tuvieran un cierto protagonismo, pero se producirá un cambio de actitud a principios del siglo VII.( Hen, pp. 33 - 41). Para la unción regia habrá que esperar a la centuria siguiente, cuando Pipino fue ungido en Soissons en 751 primero, después lo será por Esteban II. Por esta ceremonia el monarca pasaba de ser un aliado de los eclesiásticos, tal como había sido Clodoveo, al ungido del Señor como habían sido los reyes de Israel bajo la Antigua Ley (Enright, 1985). Para Jacobson este uso no era una originalidad franca del momento, con manifiestas raíces veterotestamentarias, sino que la idea se fundamen- caroligio/otónida. Sólo con la introducción del nuevo ritual a finales del siglo XI, consagración y coronación serán prácticamente idénticas en España y el resto de Europa. En las líneas que siguen esbozaremos el imaginario que definió la unción regia desde su creación en el siglo VI hasta la undécima centuria.

Hace años señalaba como en la época que Isidoro de Sevilla escribía sus Etimologías la unción no era practicada por los monarcas visigodos $^{4}$. El doctor hispalense comentaba la unción en dos referencias concretas en relación con el tema que nos interesa aquí, pues los cristianos eran ungidos por diferentes actuaciones sacramentales: la unción significaba la santificación del alma ${ }^{5}$. Sin embargo existía una unción especial "como se ve en la Antigua Ley, en la que solía ungirse a los elegidos para el sacerdocio y para el poder real, por lo cual Moisés ungió a Aaron"6. Vuelve a insistir en lo mismo en la VII Etimologia, pero introduciendo una comparación con lo que ocurría en sus tiempos: "y del mismo modo que hoy día los reyes ostentan la insigne vestidura de la púrpura como símbolo de la dignidad regia, así entre ellos -los judíos- la unción con el sagrado crisma confería el nombre y la potestad de rey"7. El mismo Isidoro nos había informado cuando los reyes visigodos habían comenzado a utilizar la púrpura y otros elementos emblemáticos de su condición de reyes. Así nos

taba en antecedentes escriturarios expuestos por Gregorio Magno e Isidoro de Sevilla (Paul A. Jacobson, p. 269). Este autor, frente a lo que tradicionalmente se dice y nosotros defendemos aquí, afirma que ni la unción de los monarcas godos ni la de los irlandeses fueron conocidas o tenidas en cuenta por los francos. Para Jacobson Pipino pudo haber conocido la unción del rey Aidan de Dál Riata que aparece en el libro XXV de la Collectio canonum hibernensis a través de Virgilio de Salzburgo, monje irlandés que frecuentaba su corte, pero ni siquiera esto habría sido decisivo para su incorporación al nuevo ceremonial franco (Idem, p. 270).

5 Aunque no es necesario explicar esto en detalle, pues es de sobra conocido, conviene recordar aquí que cualquier cristiano estaba ungido. Por esta razón cuando se hablaba de los judíos que habían recibido los sacramentos se les consideraba ya ungidos -canon LVII del IV Concilio de Toledo(Vives, pp. 210 - 211).

6 Etymologiarum VI, 19, 51 (Etimologías, I, p. 617)

7 Etymologiarum VII, 2, 2 (Idem, 633). Este es uno de las famosas expresiónes "nunc" empleadas por Isidoro para referirse a hechos que ocurrían en su época. 
informa sobre Leovigildo (572 - 576): "Fue el primero que se presentó ante los suyos en solio y cubierto de la vestidura real (regali ueste), pues antes de él, hábito y asiento eran comunes para el pueblo y para los reyes"8. Desde entonces hasta el reinado de Suintila (621-631), los monarcas visigodos terminaron por adquirir todo el repertorio correspondiente a la emblemática regia. A este respecto resultan paradigmáticas las palabras de los padres del IV Concilio de Toledo al referirse a como Suintila manifestó públicamente su renuncia al reino: "se despojó de las insignias del poder (potestatis fascibus)". Se ha discutido mucho sobre estos regalia (corona/diadema, cetro, trono, etc). Desde la época de Leovigildo y sus inmediatos sucesores son indiscutibles, aunque la ceremonia de su imposición no se haya podido fijar documentalmente ${ }^{10}$. Desde mi punto de vista, el proceso de ritualización de todo lo que se refiere a la imagen regia iniciado con Leovigildo terminaría por consolidar un ceremonial para ello. Pero todo esto, no me preocupa hoy aquí, sino el tema de la unción regia y su materialización en imágenes plásticas.

La primera unción perfectamente documentada corresponde a la del rey Wamba $(672-680)$, quien, muerto Recesvinto, fue elegido como rey, pero no aceptó el nombramiento hasta que recibiera la señal de la sagrada unción (sacrae unctionis uexilla) en la sede regia de Toledo. De regreso a la capital, la ceremonia de la unción tuvo lugar ante el altar de la iglesia palatina de los Santos Pedro y Pablo. Aquí el pontífice Quirico, con sus manos, derramó el óleo sobre la coronilla del monarca que permanecía de rodillas; realizada la bendición, al momento se manifestó una señal de salvación ${ }^{11}$. Pablo, el duque rebelde,

8 Las historias de los godos.., p. 259.

9 Vives, 1963, p. 221.

10 Durante los últimos años la obra que ha servido de referencia para el tema de la ordenación regia durante el período que aquí nos interesa ha sido la de Claudio Sánchez Albornoz, "La Ordinatio Principis en la España goda y postvisigoda", en Viejos y nuevos estudios sobre las instituciones medievales españolas, II, Madrid, 1976, pp. 1173 - 1207. Desde entonces han sido numerosos los estudios dedicados al tema por parte de los especialistas. Me es imposible en un espacio como el que dispongo aquí enunciar el estado de la cuestión, salvo las obras concretas que reseñaré a lo largo del presente estudio. Resulta de enorme interés, para un panorama crítico de historiografía del tema, el trabajo de Ayala Martínez, exhibe su condición de ungido para armarse de autoridad al dirigirse a Wamba: In nomine Domini Flauius Paulus unctus rex orientalis Wambani regi austro $^{I 2}$. Pero serán las decisiones del XII Concilio de Toledo (681), las que nos darán algo más de luz sobre el significado de la unción regia. Como es bien sabido se trataba de legitimar el nombramiento de Ervigio (680 - 687) como rey después de la deposición de Wamba. Julián, metropolitano de Toledo, aseguraba que Wamba había dispuesto que su sucesor fuera Ervigio y que recibiera la unción: mox per scribturarum definitionis suae hunc inclytum dominum nostrum Ervigium post se praelegit regnaturum, et sacerdotali benedictione ungendum ${ }^{13}$. Después de exponer prolijos testimonios de lo dicho, y para que no existiese ninguna reserva al respecto, todos los obispos en común tuvieron al monarca por consagrado. Todo esto nos demuestra que no era cosa baladí la unción regia. ¿Por qué razón? Las mismas actas del concilio nos informan de ello indirectamente al referirse a como se había nombrado rey a Ervigio: subió al trono (princeps regni conscenderit culmen); recibió la potestad de reinar por la sacrosanta unción (regnandique per sacrosantam unctionem susceperit potestatem). Creo que con estas expresiones se diferencian claramente dos actuaciones institucionales diferentes, aunque complementarias. La primera se corresponde con la elección del príncipe según las fórmulas de participación bien conocidas, pues contamos con testimonios documentados ${ }^{14}$. Pero para la liturgia y el protocolo no dejaba de decirse que el príncipe era el elegido por designio divino. Era algo similar a como se realiza la elección del papa por los cardenales de manera real, pero que se expresa como la inspiración del Espíritu

pp. $47-49$ y $175-179$

11 At ubi uentum est, quo sanctae unctionis uexillam susciperet, in praetoriensi ecclesia, sanctorum scilicet Petri et Pauli, regio iam cultu conspicuus ante altare diuinum consistens, ex more fidem populis reddidit. Deinde curbatis genibus oleum benedictionis per sacri Quirici pontificis manus uertici eius refunditur et benedictionis copia exibetur, ubi statim signum hoc salutis emicuit (Historia Wambae regis, 4). Esta señal es la conocida historia de las abejas.

12 Sancti Iuliani Toletanae Sedis Episcopi Opera, CXV, Pars I. 13 Vives, p. 386.

14 "El rey será elegido con el voto de los obispos y de los más nobles del palacio", VIII Concilio de Toledo (653), c. X (Vives, p. 283). 
Santo. Al príncipe elegido le faltaba la consagración (sacre du roi), esta era una acción sacramental, la unción regia, que solo podía practicar un obispo. Sin ella carecía de potestatem regnandi $i^{15}$. Debía servirse al Dios del cielo, pero después de él sería al príncipe consagrado al que habría que servir con piadosa devoción ${ }^{16}$. Esta idea de ser el que gobierna después de Dios ya está presente en la época de Recaredo. Este monarca expresaba ya este concepto al solicitar del papa Gregorio, obispo de Roma, su bendición "para nosotros Recaredo- y para nuestro pueblo que gobierno después de Dios"17. Los asistentes al III Concilio de Toledo no dudaron en considerar a Recaredo igual a los apóstoles: Ipse mereatur veraciter apostolicum meritum qui apostolicum implevit officium ${ }^{18}$. El monarca también se expresa "lleno de inspiración divina", tal como vemos a Recaredo dirigirse a los presentes en el III Concilio de Toledo ${ }^{19}$. Y lo mismo sucede con Chintila al dirigirse a los asistentes al V Concilio de Toledo (636): atque hanc institutionem, quam ex praecepto eius et decreto nostro sancimus, divina inspiratione praemisit $t^{20}$. Como "ministro" de Dios debe intervenir en los asuntos civiles y en los negocios divinos ${ }^{21}$. Y como no podía ser menos su intervención en lo eclesiástico, tal como vemos en los términos que expresan los padres conciliares con respecto a Recesvinto: "damos gracias al serenísimo señor nuestro rey Recesvinto, cuya vigilancia gobierna los asuntos civiles con suma misericordia, y los eclesiásticos los dispone con la mayor perfección con la sabiduría que le ha sido concedida de lo alto"22. En este contexto no es extraño que cualquier manifestación del monarca sea reconocida como sacratisima $^{23}$. Y por último, que el monarca sea conocido como "Rey en el nombre del Señor".

15 Conviene ver aquí un claro reflejo de la concesión de la "potestad de reinar" que Isidoro nos decía que el óleo concedía a sacerdotes y monarcas del Antiguo Testamento, tal como hemos comentado más arriba.

16 Así se expresaban los padres del XII Concilio de Toledo al referirse a Ervigio como monarca consagrado: serviendum est sub Deo caeli paedicto pincipi nostro Ervigio regi cum pia devotione, canon I, (Vives, p. 387).

17 Idem, p. 145.

18 Idem, p. 117.

19 Idem, p. 108

20 Idem, p. 226.

21 Asi se habla de Sisenando en el IV Concilio de Toledo (633): Post haec antefacto ministro - el rey Sisenando- ...
Según cuenta la historia que refiere la unción de Wamba esta era una costumbre (ex more). El problema está en fijar cuándo se estableció la unción. Son muchos los especialistas que han dado respuesta a este interrogante, proponiendo generalmente dos nombres: Recaredo o Sisenando. Recientemente se ha afirmado que el primer monarca visigodo ungido fue Hermenegildo $^{24}$. Las atribuciones a favor de uno $\mathrm{u}$ otro candidato participan de ciertos argumentos verosímiles, pero no concitan la unanimidad de los investigadores. El conocimiento del tema en estos momentos solo nos permite afirmar que el rey visigodo era ungido en el año 633, pues un canon del IV Concilio de Toledo, dedicado a proteger al monarca afirma lo siguiente: "No toquéis a mis ungidos, y David añade: ¿Quién extenderá la mano contra el ungido del Señor y será inocente? Para los tales no es perjurio el evitar los peligros ni el causar la pérdida a sus reyes" ${ }^{25}$. Parece evidente que ya entonces los monarcas, tal como lo había sido el rey David, eran ungidos. Las expresiones empezadas a utilizar con Recaredo, "juramento", "gobierno después de Dios", "igual a los apóstoles", etc son una clara muestra de un proceso de sacralización de la monarquía goda que nadie discute, sin embargo bajo ningún concepto se practicaba la unción, pues el nunc que hemos citado en la VII Etimologíarum lo deja muy claro. El Hispalense, al redactar este pasaje, no podía olvidarse de un hecho fundamental para su argumentación durante su propio presente. La cronología de la redacción de las Etimologías es ampliamente discutida, incluso se habla de dos ediciones. Por no entrar en la complejidad de este tema creo que, si señalamos un marco cronológico amplio, como 620-632, estaríamos incluyendo la totalidad de las diferentes propuestas ${ }^{26}$.

ut non solum in rebus humanis sed etiam in causis divinis (Idem, p. 186).

22 Canon XXIII del Concilio de Mérida, del año 666 (Idem, p. 342).

23 Con este término reconocen el sacratissimo voto del rey Recesvinto en la inauguración del X Concilio de Toledo, año 656 (Idem, p. 308). Serían innumerables los títulos del tipo cristianísimo, piadoso, religiosísimo, amante de Cristo, etc

24 Barroso, Morín y Velázquez, p. 502.

25 Canon LXXV (Vives, 1963, p. 217).

26 Díaz y Díaz, M., pp. 170 - 174. 
Llevando estas datas al extremo sólo se pudo establecer definitivamente la unción bajo el reinado de Sisenando (631 - 636), acortándolas ligeramente podría haberse producido con Suintila. En todo caso, desde Recaredo, reyes y obispos habían dotado a la figura regia de un carácter teocrático que necesitaba de un ritual que la institucionalizase. Por los escritos de Gregorio Magno y las citadas referencias etimológicas de Isidoro, esa ceremonia no podía ser otra que la unción de sacerdotes y reyes veterotestamentarios.

Durante los oscuros y turbulentos 24 años que restaban a la monarquía goda después de la documentada unción de Ervigio ninguna noticia volvemos a tener sobre el tema. Hace unos años, cuando la historiografía se inclinaba por el indigenis-

27 He tratado el tema en numerosas publicaciones desde hace treinta años, por evitar un larguísimo excusus bibliográfico baste citar aquí como resumen y referencia de todas las publicaciones mi trabajo de 2001, espec. pp. 227 317. La tesis básica es la siguiente: Alfonso II, monarca de una conocida formación monástica, es el verdadero creador de la teoría del reino astur, cuyos reyes se consideran herederos directos de los visigodos. El y su entorno monástico necesitan recrear en Oviedo la figura de un rey godo con todo el aparato representativo que esto requiere. Que lo consiguió es un claro testimonio que fuera reconocido como Magno por las crónicas inmediatas a su reinado. La acción edilicia de este monarca así como el significado de las obras promovidas por él son, según mi criterio, el mejor exponente de su ideario político y de su peripecia vital. Cesar García ha cuestionado mi tesis negando aspectos parciales de los argumentos. He puesto en paralelo el proyecto político de Alfonso II dando forma al núcleo de resistencia astur con la labor de Leovigildo. Se extraña García que yo haya señalado un personaje como Leovigildo tan negativo para los cristianos, pues, según él, será Recaredo el verdadero modelo. Creo que es excelente la aportación que hace señalando ciertos textos alfonsinos inspirados en las actas del III Concilio de Toledo. Sin embargo lo que no puede olvidarse es como los propios católicos modificaron sustancialmente su opinión sobre Leovigildo. Pero por centrarnos en el tema de los reyes de Oviedo, me desconcierta que un experto "asturianista", que pretende, con mucha razón, defender la figura de Recaredo como modelo, no tenga presente dos cosas que están meridianamente claras en las crónicas. El Albeldense, cierto que señala la militancia arriana y el anticatolicismo de Leovigildo, pero no deja de valorar lo que llamaríamos hoy un gran "hombre de estado", convendría comparar este aspecto con lo que dice de Recaredo a continuación. Precisamente por esto, la Crónica de Alfonso III (A Sebastián, 13) intentando dar mayor fuerza a la idea de linaje godo de algún príncipe astur con nombres indiscutibles no le basta decir Recaredo, que sí que es el primer rey católico, pero no es el "primero" y el más grande por su actividad política: ex semine Leunegildi et Recaredei regum. Hay muchos aspectos de Alfonso II que inciden en señalar su formación monástica que me han hecho decir que mo, o por la inclusión en la órbita carolingia o por el neovisigotismo creado por Alfonso III, para explicar la teoría política de la monarquía astur, creo haber demostrado que fue Alfonso II y la "inteligencia" eclesiástica de su entorno quienes crearon un programa político neovisigótico de la monarquía que la fundamentase y, a su vez, argumentase la legitimidad de la salus Hispaniae ${ }^{27}$. Es en este contexto de definición de la imagen real de la época astur donde vuelve a aparecer el rey ungido de época visigoda. La Crónica de Alfonso III (versión rotense) se refiere en estos términos a Alfonso II (791 - 842): Hunctus est in regno predictus rex magnus Adefonsus ${ }^{28}$. Volvemos a encontrarnos con otro texto cronístico que nos refiere una nueva unción la de Ordoño II, rey de León (914 - 924). Según la Historia Silense,

si no era un monje, al menos vivía como tal. Uno de ellos se refiere al aniconismo, característica de la elite religiosa hispana, que tanta trascendencia tendrá no sólo en el ámbito peninsular, sino en el del imperio carolingio. Para García el término absconditus que Alfonso atribuye a Dios en su célebre "testamento" tiene una alambicada interpretación teológica en relación con Jacob, pero lo que olvida este investigador es que, en la copia más antigua, una mano muy posterior escribió lo que para él significaba, con toda razón, dicho término: invisibilis. La copia del siglo XIII sustituye el término absconditus y escribe directamente invisibilis. No puedo entrar aquí con todo detalle en lo que un Deus invisibilissignifica, pero sí una pequeña aclaración: anatema para los que sostengan que la divinidad sea visible (c.IX, III Conc. De Toledo); los padres del VI Conc de Toledo se refieren a Dios como "autor invisible de todas las cosas"; los asistentes al décimo de Toledo inician el mismo dando las gracias "al Dios invisible". No hay ninguna duda que en estas referencias conciliares y en tantas más de carácter teológico que pudiésemos añadir significa la no materialización de la figura divina. Por último, coincido con él en la necesidad de que se haga un estudio sobre la expresión servus empleada por Alfonso II, mientras tanto sigo pensando que en Alfonso es un dato más de ese sentimiento monástico en el que se ha formado. De los ejemplos que aporta García, quisiera decir dos cosas: servusno solo es monástico sino de hombres de iglesia en general, siempre se ha dicho y yo no lo he negado, pues es tan evidente para quien conozca las fuentes; lo que si es verdad, o al menos yo no conozco, es que el término figure en ningún documento original de época ástur en relación con personas que no sean de condición religiosa en general, lo que sucede a partir de la dinastía asturleonesa es otra cosa. Para los argumentos de César García de Castro, pp. 160-161 y notas 9 y 11.

28 Crónicas Asturianas, p. 138. P. Linehan niega la realidad histórica de esta unción (pp. 97 y ss.). Por otro lado, existe también la postura no solo contraria, sino que hace extensiva la unción en la monarquía astur desde la misma época de Pelayo (Besga Marroquin, pp. 418 y ss). Conviene recordar que la Crónica de Alfonso III se inicia con el rey Wamba, indicando que el reinado de este tuvo su origen en la elección y a continuación su unción. 
todos los magnates, obispos, abades, condes y primates de España celebraron una junta general solemne, y aclamándole, se le impuso una diadema, y fue ungido por doce pontífices en el solio real, en León ${ }^{29}$. En 1111 tiene lugar una ceremonia de unción/coronación completa: la del príncipe Alfonso, hijo de Urraca y Raimundo de Borgoña, en la catedral compostelana, y oficiada por el mismo Gelmírez. "El obispo, vestido de pontifical, y los otros clérigos convenientemente revestidos con los ornamentos eclesiásticos, le recibieron en gloriosa procesión. Tomándolo el pontífice le condujo con ánimo gozoso ante el altar de Santiago apóstol [...] y allí, según normas de los cánones religiosamente le ungió como rey, le entregó la espada (ensem) y el cetro (sceptrum) y, coronado con diadema de oro (auro diademate), hizo sentar al ya proclamado rey en la sede pontifical. Luego, una vez celebrada la misa solemnemente según lo acostumbrado... ${ }^{30 "}$ Todos los ceremoniales de coronación relacionados con reyes hispanos, desde el siglo XII al XV mantienen el mismo esquema: unción y entrega de las principales insignias reales (espada, cetro y corona), aunque introduciendo pequeñas variantes en el desarrollo del ceremonial ${ }^{31}$.

La falta de una información continuada sobre el tema desde el siglo VI hasta el XI ha hecho que una parte de los historiadores que se ha ocupado de la unción sea escéptica sobre su práctica ${ }^{32}$. La primera respuesta que habría que dar ante este

29 Eum adclamando sibi constituit, impositoque ei diademate, a XII pontificibus in solium regni Legione pervnctus est (Historia Silense, p. 155). Dada la contextualización de la unción regia en los libros litúrgicos del momento, hace innecesario entrar aquí en la polémica sobre si se produjo o no dicha ceremonia. La "Nómina de los reyes católicos leoneses" también nos informa que Ramiro II (931 - 950), tercer hijo de Ordoño II, "fue ungido el 6 de noviembre..." (Crónicas Asturianas, p. 246).

30 Historia Compostelana, Lib. I. cap. LXVI, p. 174.

31 Bango Torviso, 2000, espec. 25-26.

32 Vid nota ${ }^{\circ} 10$

$33 \mathrm{Si}$ es cierto que contamos con el conjunto de cantos, antífonas, oraciones etc, que constituye el aparato del ritual, no lo es menos que carecemos del libellus del ceremonial de coronación e incluso de las rúbricas correspondientes.

34 Las tres lecturas correspondientes a la "Ordenación del Rey” se encuentran en Liber Commicus t. II, pp. 535 - 537.

35 Las citas al texto de este antifonario se harán a partir de la edición de Brou y Vives. Sobre su cronología existen serias discrepancias que pueden situarse en un marco cronológico que va del siglo X al XI. Centrándonos sólo en el texto del antifonario, todos los investigadores coinciden en que reproduce en su mayor parte un original del siglo VII. escepticismo es que la mayoría de los conceptos y teorías que se emiten sobre esta época, incluidos los que ellos mismos defienden, no tienen más argumentos de apoyo. Para una ordenación del rey, conteniendo la unción con un protagonismo excepcional, contamos con lo que denominaríamos la teoría litúrgica completa, perfectamente codificada en la época de Eugenio de Toledo y mantenida hasta el siglo $\mathrm{XI}^{33}$. Aunque para hablar de este tema se suele citar siempre el célebre antifonario leonés, especialmente por su conocida ilustración de la que nos ocuparemos a continuación, las obras rituales son las tres siguientes: las lecturas del Liber Commicus/Leccionario, correspondientes al apartado Legendum in Ordinationis regis $^{34}$; las antífonas que se cantan en el oficio de la ordenación o natalicio del rey, recogidas en el Antifonario de la catedral de León ${ }^{35}$; un Ordo pro solo rege con sus respectiva misa en el Liber Ordinum Episcopal/Pontifical ${ }^{36}$. Creo que las noticias históricas referenciadas más la existencia de este aparato ritual no deberían dejar lugar a la duda sobre la existencia de una parte fundamental de la ceremonia, la unción. Al faltarnos el libellus del ceremonial y las rubricas tendremos que seguir la información de las antífonas para intentar reconstituir una secuencia del ceremonial regio. La composición del antifonario se organiza en los siguientes apartados ${ }^{37}$ :

36 El Liber Ordinum episcopal reúne el texto del códice silense, del año 1052, y el de San Millán de la Cogolla, de finales del siglo X. Los textos correspondientes a Ordo Missae uotibae de rege (texto silense), pp 234 - 237; idem en el texto emilianense pp. 372- 374. El contenido se atribuye en esencia a la actividad litúrgica de Julián de Toledo (680-690), con añadidos que se consideran de época astur hacia el 800 (pp. $44-46)$.

37 Para una mejor comprensión de las fases generales reproduzco a continuación los siguientes apartados secuenciales del antifonario (pp. $450-452$ ): $\mathbf{1}^{\circ}$.-Un canto de gloria y honor al Señor, Dios del cielo, etc. $\mathbf{2}^{\circ}$.- Antífona dirigida al príncipe que va a ser coronado, basada en Isaías $(16,5)$ : Prepararé -Dominus- para ti -principem- el trono para juzgar y ser justo. $3^{\circ}$.- Un alleluiaticum siguiendo a Isaías (41, 9-10): Tú eres mi siervo, te he elegido y estoy contigo... $4^{\mathbf{0}}$.- Se continúa salmodiando las palabras de Dios a Jacob (Génesis, 48, 4): yo te acrecentaré y te daré tierra para ti y para toda tu descendencia... $\mathbf{5}^{\circ}$.- Antífona para la que no se ha encontrado un tipo exacto: "Y el Señor dijo: Te elegí príncipe para mi pueblo. Andarás por donde quieras para que alabes mi nombre sobre todos los pueblos". $6^{\circ}$.Aleluya, siguiendo las palabras de Dios a José (Génesis, 41, 40): Te elegí para que fueras príncipe para mi pueblo y a tu 
La ceremonia se inicia con una primera fase de canto a la gloria de Dios y como este eligió al príncipe para gobernar a su pueblo (aparta$\operatorname{dos} 1^{\circ}$ a $6^{\circ}$ ). La primera antífona alude directamente al trono siguiendo las palabras de Isaías. No soy capaz de precisar si se refiere a que en ese momento se le entroniza o simplemente se utiliza de manera figurada, pues el "sedebis super eum-solium-" del canto puede aludir perfectamente a una acción de futuro, una vez que fuese consagrado.

Sigue una preparación para la ceremonia de la unción (apart. $7^{\circ}$ y $8^{\circ}$ ): Cantos en referencia a la unción de David en Hebrón y otros con relación a la protección del príncipe por el Señor ciñendo su cabeza con las manos. Se termina esta parte con una antífona para la que los especialistas no conocen que exista un tipo testamentario específico: Unxit te dominus deus tuus. Yo diría que sería la antífona que se canta mientras el prelado realizaba la unción regia propiamente dicha (apart. $9^{\circ}$ ).

A continuación una nueva antífona nos anuncia que en ese momento se está produciendo la coronación: posuisti in capite eius choronam de lapide pretioso (apart. $10^{\circ}$ ).

El acto final de la ceremonia nos muestra una especie de manifestación pública del rey. El ritual, que se debía celebrar en el coro ante el altar, permitía que el rey avanzase hacia una parte que facilitase su visión por los que estaban en el templo. Me atrevería afirmar que este sitio sería la porta chori. El texto dice literalmente: Processit princeps stolam habens regalem et coronam auream et dia-

orden obedecerá todo el pueblo de Israel. $\mathbf{7}^{\mathbf{}}$.- Sigue otro aleluya, relacionado con la unción de David en Hebrón (I Paralipómenos, 11, 2): Tú cuidarás de mi pueblo y cuidarás que se cumplan mis mandatos etc. $\mathbf{8}^{\mathbf{0}}$.- Responsorio basado en el texto de salmo 138(5-6), invocando al Señor que todo lo conoce y que ciñe con su mano protectora la cabeza del príncipe... $9^{\mathbf{0}}$.-Antifona que literalmente dice: "Te ungió el Señor, tu Dios". $\mathbf{1 0}^{\mathbf{0}}$.- Antífona: "Te adelantaste con fausta bendición y pusiste la corona de piedras preciosas sobre su cabeza. Te pidió vida y se la concediste larga y eterna (Salmo, 20, 4-5). $\mathbf{1 1}^{\circ}$.- La antífona siguiente tampoco tiene fundamento textual, parece escrita ex profeso: "Se adelantó el príncipe teniendo el manto real (stola regalem) y la corona aurea. Contemplándole las gentes, están alegres. Toda la ciudad está contenta". 12.- A continuación una antífona insiste en esta alegría por la coronación, identificando a los presentes con los habitantes de Jerusalén: Viri Iherusalem
dema.Al verle las gentes vitorean llenas de júbilo. Nada se nos había informado sobre la túnica real, pero por comparación con otros ordines regios, esta se coloca una vez que ha sido ungido no recibiendo un tratamiento ritual específico, pues para la unción debe tener el torso descubierto. Volveremos sobre ella al tratar del Sacramentario de Warmondo de IvreaEsta manifestación real produce gran alegría a los presentes entonándose entonces dos antífonas: una enfatiza la coronación (apart. $12^{\circ}$ ), mientras que la otra pone su énfasis en la unción al compararla con la del rey David (apart. 13º. Los dos últimos apartados se dedican a la protección divina y al agradecimiento del nuevo rey (aparts. $14^{\circ}$ y $15^{\circ}$ ).

El Liber Ordinum presenta una serie de actuaciones en correspondencia con lo que hemos llamado la primera fase: Iniciándose con una rotunda antífona: "Señor, salva al rey..."; sigue una oración solicitando que se acepte la ofrenda del príncipe; el texto de Jeremías $(23,5-8)$ que recuerda como el príncipe como un vástago de David "faciet iudicium et iustitiam in terram". Viene a continuación la solicitud del príncipe pidiendo ayuda al Señor para ejercer sus funciones: "ten piedad de mí... fortalece a tu siervo... enséñame, Señor, los caminos..." (Salmo, 85, 16 y 11). El Señor responde "cumplí los deseos de tu corazón, todos los anhelos de tu alma" (Salmo, 19, 5). Ambos salmos serían previos o simultáneos a la preparación de la unción (apartados $7^{\circ}$ y $8^{\circ}$ ). Cuando el rey, una vez ungido y coronado se presenta mayestáticamente produciendo la alegría de las gentes, se pronuncian las palabras de la

exite et videte principem cum coronam quia coronabit eum dominus in die sollemnitatis et laetitie (Cantar de los Cantares, 3,11$) \cdot \mathbf{1 3}^{\circ}$.- Sigue el salmo que alude a la unción de David y como la mano de Dios le auxilia y su brazo le confortará: Inveni Davit sevuum meum oleo sancto unxi eum. Manus enim mea auxiliabitur ei et brachium meum confortabit eum. Oleo (Salmo, 88, 21). 14º.- Se salmodia el gozo del rey por la ayuda divina: Domine in virtute tua letabitur rex et super salutare tuum exultabit valde (Salmo, $20,2) . \mathbf{1 5}^{\circ}$.- Se expresa el sacrificium, siguiendo fragmentos de II Paralipómenos $(7,18 ; 8,12)$ : Se expresan las palabras de Dios a Salomón, atribuidas en este caso al príncipe coronado, agradeciéndole los sacrificios que le había ofrecido y reiterándole lo que ya le había prometido: sustentará su trono y siempre ocupará este un miembro de su estirpe. 
Epístola de Timoteo (I, 1,18; 2, 1-4), solicitando de todos "que hagan peticiones por los emperadores...", recordándose las palabras de Mateo "pedid y se os dará". Se termina el apartado con "Señor, salva al rey...". La actuación durante el sacrificiumsirve para salmodiar los sacrificios de alabanza (Salmos, 49, 14; Job, 2, 3). Se termina con la siguiente admonición al nuevo monarca: "Bien te ha sido declarado lo que es bueno y lo que de ti se pide: hacer justicia, amar el bien, humillarte en la presencia de tu Dios" (Micheas, 6,6).

Si todos estos textos nos permiten hacernos una idea de la imagen que se quiere del monarca, sin duda serán las lecturas de la misa las que mejor lo definan. El Commicus señala tres lecciones. La primera corresponde al Libro de la Sabiduría (Lectio Libri Sapientie Salomonis, IX, 1-12). En esencia son las palabras de Salomón para que Dios le conceda sabiduría para ser justo en sus juicios y piadoso erigiendo el templo del señor. La segunda lectura corresponde a la Epístola del apóstol Pablo a los Romanos (XIII, 1-8). Se pretende con este texto enseñar al pueblo que debe estar sometido a la autoridad y pagar sus tributos, pero dirigiéndose al rey, que se le identifica como ministro de Dios (minister Dei), no duda en decir: "porque es ministro de Dios para el bien. Pero si haces el mal teme, que no en vano lleva la espada. Es ministro de Dios, vengador para castigo del que obra mal". Del rey visigodo como ministro de Dios nos hemos ocupado anteriormente. La tercera lectura se refiere a la unción expresada por Cristo al leer en la sinagoga el texto de Isaías: Spiritus Domini super me: propter quod uncxit me... (Lucas, IV, 1-8). A manera de conclusión diría que las enseñanzas de las tres lecturas se podrían resumir en los siguientes principios referidos al rey: 1) ha de ser justo y piadoso; 2) se le deberá sometimiento a las leyes y sino,

38 Si contenido y caracteres paleográficos han producido las dataciones diferentes que hemos citado, tampoco existe una gran precisión para la cronología de las ilustraciones. Se acepta sin más el año que se expresa en uno de los prólogos, 1069 ( $\mathrm{M}^{\mathrm{a}}$ Elena Gómez Moreno, M.E., p. 314), o se amplia a un marco cronológico que va desde la segunda como ministro de Dios, dispone de la espada para castigar; 3) como ungido se ocupará de las cosas divinas contribuyendo a la difusión del mensaje de Dios.

Se ha considerado que la primera imagen de la unción de un rey hispano es la que figura en el Antifonario de la catedral de León ${ }^{38}$. Corresponde a la ilustración del OFICIUM IN ORDINATIONE SIVE IN NATALICIO REGIS, cuyo texto se extiende del folio $271 \mathrm{v}^{\circ}$ a $273 \mathrm{r}^{\circ}$. El término natalicio que ha dado lugar a algunas dudas interpretativas, no significa otra cosa que el dies natalis de los santorales, es decir el día que con su muerte un santo adquiere esta condición. En este mismo sentido, el día de la ordenación del monarca, este pierde su condición de un simple hombre para convertirse en rey.

La ilustración del oficio [Fig. 1] figura con una ausencia total de espacio delimitado, pues carece de marco y de fondo. Se compone la escena de tres personajes: dos de pie, mientras

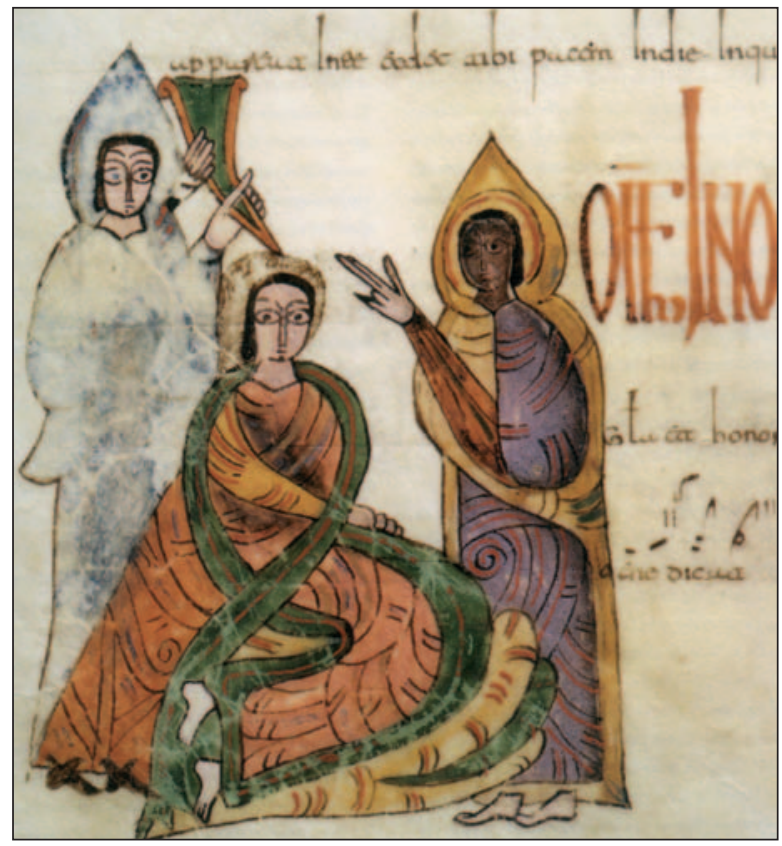

Figura 1

mitad del siglo X a la primera del XI (Yarza Luaces, p. 205). Fernando Galván que se ha ocupado de manera monográfica de la miniatura de la unción piensa que se trata de un modelo que debió crearse en el siglo X, aunque se podría haber realizado durante la centuria siguiente (Galvan, p. 145). 
que el tercero, arrodillado sobre un gran cojín, figura en medio de los anteriores ${ }^{39}$. Las dos personas de pie tienen una especie de gorro puntiagudo o capucha, elemento característico en la miniatura medieval española de los obispos, se podría considerar una mitra. La identificación parece clara: dos obispos procediendo a la unción de un monarca. Uno de los prelados sostiene en alto el cuerno con el santo oleo, por encima de la cabeza del rey, a su vez el segundo obispo bendice al monarca. Desde el punto de vista iconográfico, salvo el color de las vestiduras y la acción que realizan, nada distingue a uno del otro. Las referencias altomedievales sobre la unción regia la suelen calificar de "sacerdotal", entendido este término como episcopal, o simplemente se habla de los obispos que participan de la ceremonia. Solo sabemos que Wamba fue ungido por Quirico, urbis regiae metropolitanus episcopus, o que Ordoño II lo fue por doce obispos.

La elección de esta imagen como ilustración de la "ordenación de un monarca" ha suscitado ciertas dudas de interpretación entre los especialistas que se han ocupado del tema. En principio tenemos que decir que para la Iglesia del momento el ritual más significativo de la ceremonia es la unción regia. Por ella, una verdadera acción sacramental, el monarca se convierte en sagrado, en ministro/ángel de Dios e igual a un obispo/sacerdote al ser un ungido como Cristo para promover la palabra de Dios. Los reyes portan los emblemas de su condición (regalia), pero estos son símbolos que llamaríamos civiles aunque pudieran tener también su lectura religiosa, sin embargo el símbolo del rey como una institución sacramental es la unción tal como la denominó san Eugenio: sacrae unctionis uexilla. Es evidente que por todo esto la ilustración más lógica en este ambiente eclesiástico sea el de la unción. Tal como venimos comentando será la

39 Se ha dicho que este personaje aparecía sentado, incluso que el pintor no ha servido resolver esta forma de representarlo. Aunque la factura no es buena, no creo que haya dudas de que su posición es la de arrodillado. Como hemos visto anteriormente, Wamba se arrodilló para recibir la unción (curbatis genibus).

40 Liber primus Samuelis, 16, 13 unción de los reyes veterotestamentarios la que ha servido de modelo para la ceremonia de la unción real de los visigodos, especialmente las de David y Salomón. Se recuerda a este respecto la tradición iconográfíca bíblica que reproduce la unción de David por parte de Samuel: Tulit ergo Samuel cornu olei, et unxit eum in medio fratrum ${ }^{40}$. La utilización del cuerno del óleo de forma tan expresiva en la ilustración antifonal llevó a algunos especialistas a relacionarla con la imagen de la llamada Biblia de San Isidoro del 960: Samuel derrama el óleo sobre un David que permanece de pie junto a su padre y sus hermanos [Fig. 2 $]^{41}$. Esta fórmula iconográfica es muy antigua, incluso se seguirá manteniendo en las biblias románicas, tal como podemos contemplar en la de San Millán [Fig. 3]. No falta en esta imagen el cuerno del óleo, Samuel, el joven David y los hermanos ${ }^{42}$.

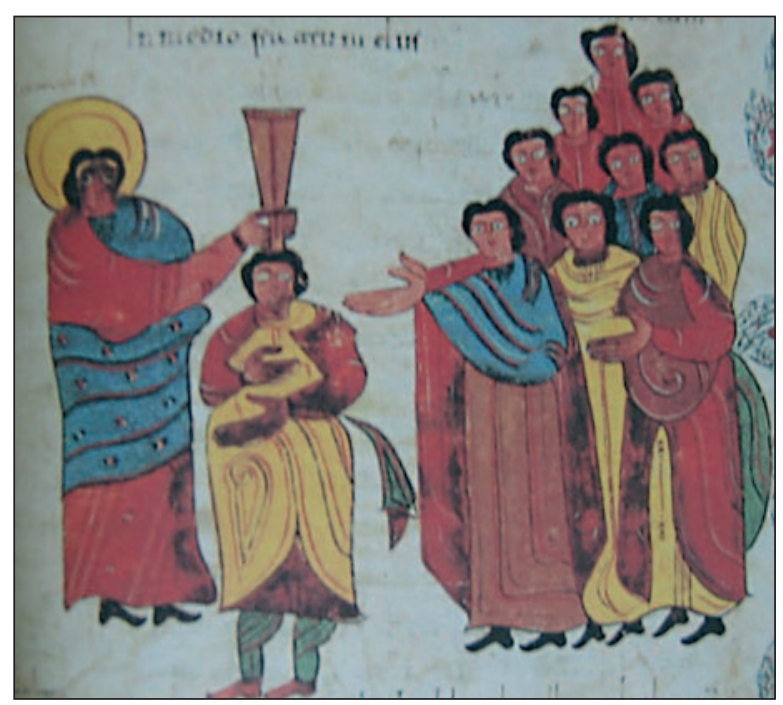

Figura 2

En el antifonario es evidente que no están los hermanos y sí dos prelados cristianos ${ }^{43}$. Esto hizo que Brou no dudase que estábamos ante un aspecto de unción de un rey cristiano. Después, todos han mantenido el mismo criterio iconográfico.

41 Los presentes deberían ser ocho personas, el padre y siete hermanos, sin embargo se han reproducido nueve.

42 La variante del número de los presentes representados resultaba algo aleatorio siguiendo diferentes tradiciones (Silva,, p. 175.

43 Brou, p. 74 , nota 88. 


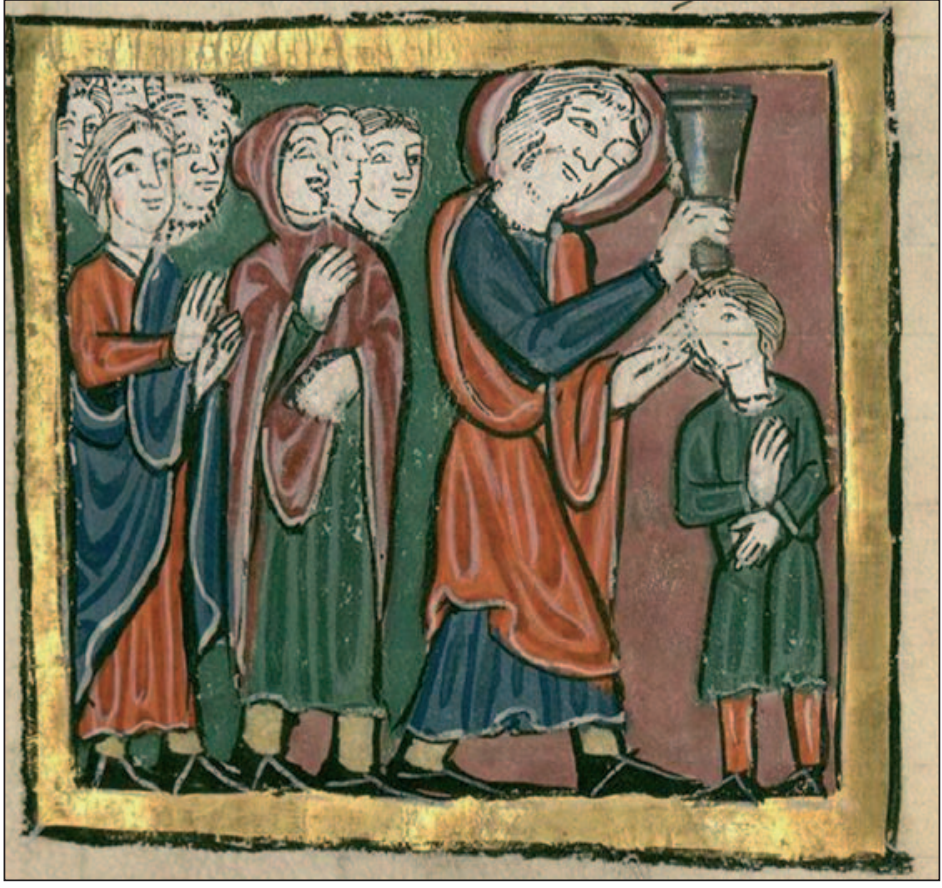

Figura 3

representando el momento en que ya aparece el monarca ungido, se ha vestido con la estola regalis que se cita en el antifonario, y recibe la bendición. La referencia a la unción se muestra con el cuerno del óleo que se mantiene por uno de los oficiantes en alto. Obsérvese que del cuerno no cae el aceite, y sin embargo el mismo pintor nos muestra en una escena de bautismo de este códice como el agua cae de la jarra del oficiante sobre la cabeza del que se está bautizando [Fig. $4]^{44}$. Es más el rey aparece con una aureola propia del ungido, mientas que el que recibe el sacramento del bautismo todavía no tiene la aureola.

Por otro lado, pienso que el miniaturista ha reproducido el cuerno de las unciones veterotestamentarias por evocación

Hay dos aspectos icónicos más que tienen un gran interés. El monarca está arrodillado, mientras que David permanecía de pie. La actitud del rey representado en el antifonario parece acorde con lo sucedido en la única unción regia visigoda que se nos ha descrito aunque sea brevemente: Wamba permanecía curbatis genibus mientras le ungían. Cabe deducir que esta sería la fórmula que se codificaría o estaría ya codificada en el ceremonial. Por otro lado, en el antifonario se ha querido dotar a la composición de una cierta pompa de carácter áulico: las lujosas vestiduras o el cojín/almohadón. Todo esto parece demostrar que estamos ante una imagen de unción real propia de la época, sin embargo la presencia del gran cuerno para el óleo me crea ciertas dudas. De semejante recipiente solo podría salir una cantidad de aceite que cayese sobre la cabeza y chorrease por esta hasta tan bella indumentaria. Por otra parte, en las unciones que ya se practicaban en el siglo X en otros lugares de Europa y en España en los ceremoniales que se conocen a partir del siglo XIIl, la unción se realizaba teniendo el príncipe la parte superior del cuerpo desnudo. Lo que me hace suponer que se está

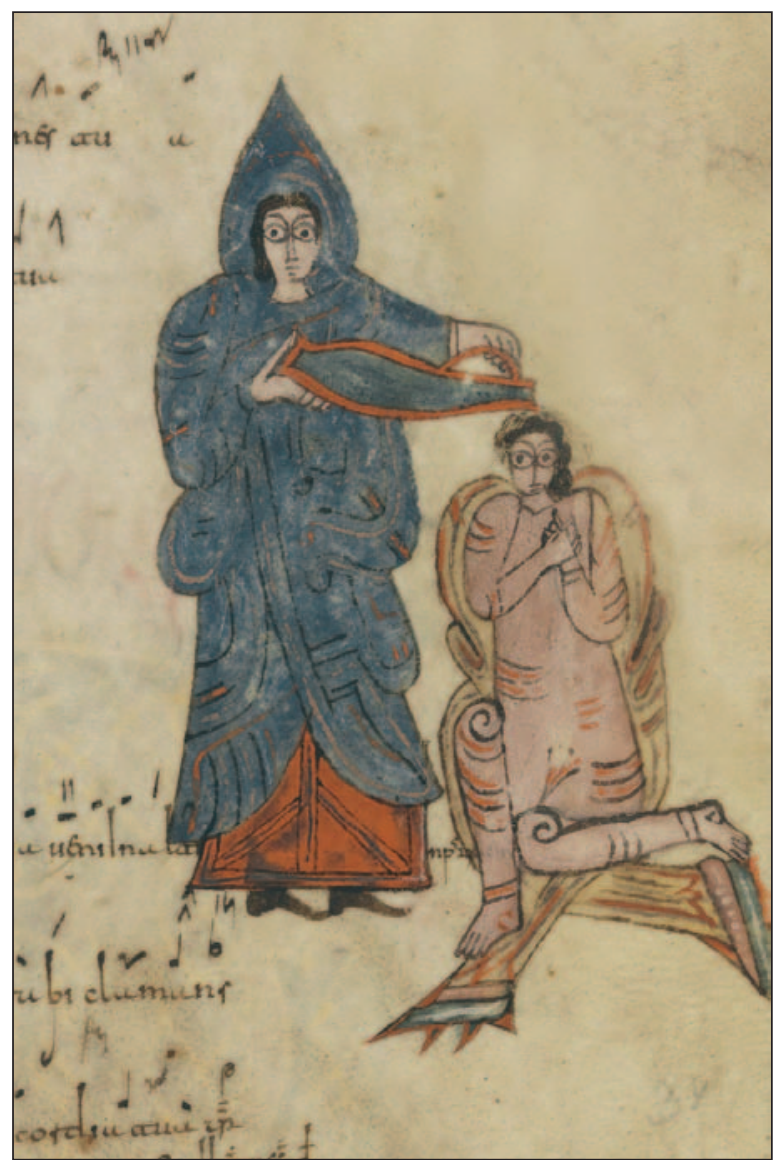

Figura 4

44 La escena corresponde a la ilustración del "Oficio de San Clemente" (Fol. 34) 
del origen de la ceremonia, pero no por realidad de la época. Lo lógico es que fuesen una o dos pequeñas ampollas contenedoras del crisma, es decir crismeras. Es posible que estas tuviesen la forma de cuerno en el caso específico de las unciones reales, pero desde luego no de gran tamaño, pues la cantidad de crisma a emplear es mínimo. Se guardarían en pequeños estuches como es lo habitual con las crismeras. Nuestra información sobre el tema es que al principio, al igual que en la unción de los obispos, esta solo se practicase sobre la cabeza. La narración cronística sobre Wamba nos dice que era exactamente sobre la coronilla, tal como ya hemos comentado. Más adelante, como se hará también con los obispos, la unción se ejecutará sobre otras partes del cuerpo.

Para interpretar mejor la imagen del antifonario veamos la siguiente miniatura. Aunque es una obra de otro contexto cultural, una miniatura del Sacramentario de Warmondo de Ivrea, posible- mente del año 1002, nos muestra una escena muy interesante de la ceremonia de la consagración regia [Fig. 5] $]^{45}$. Se ha producido ya la unción y los oficiantes proceden a cubrir el cuerpo del monarca con su túnica real, están terminando de abrochar el vestido. A su vez el metropolitano está procediendo ya al acto siguiente, la imposición de la corona. Mientras que por detrás de este grupo contemplamos un acolito que exhibe en sus manos las ampollitas o crismeras utilizadas en la unción. Es una interesantísima ilustración que, con su composición secuencial, nos está evocando en una única escena tres momentos distintos de la ceremonia. Están sugeridos desde atrás hacia adelante: el acolito de las crismeras nos evoca la unción que ya ha tenido lugar, los dos obispos abrochando la túnica regia nos indican que la unción ha terminado y se le ha impuesto el indumento real y, por último, el metropolitano procede a colocar la corona sobre la cabeza. Pienso que la imagen leonesa deberíamos interpretarla de

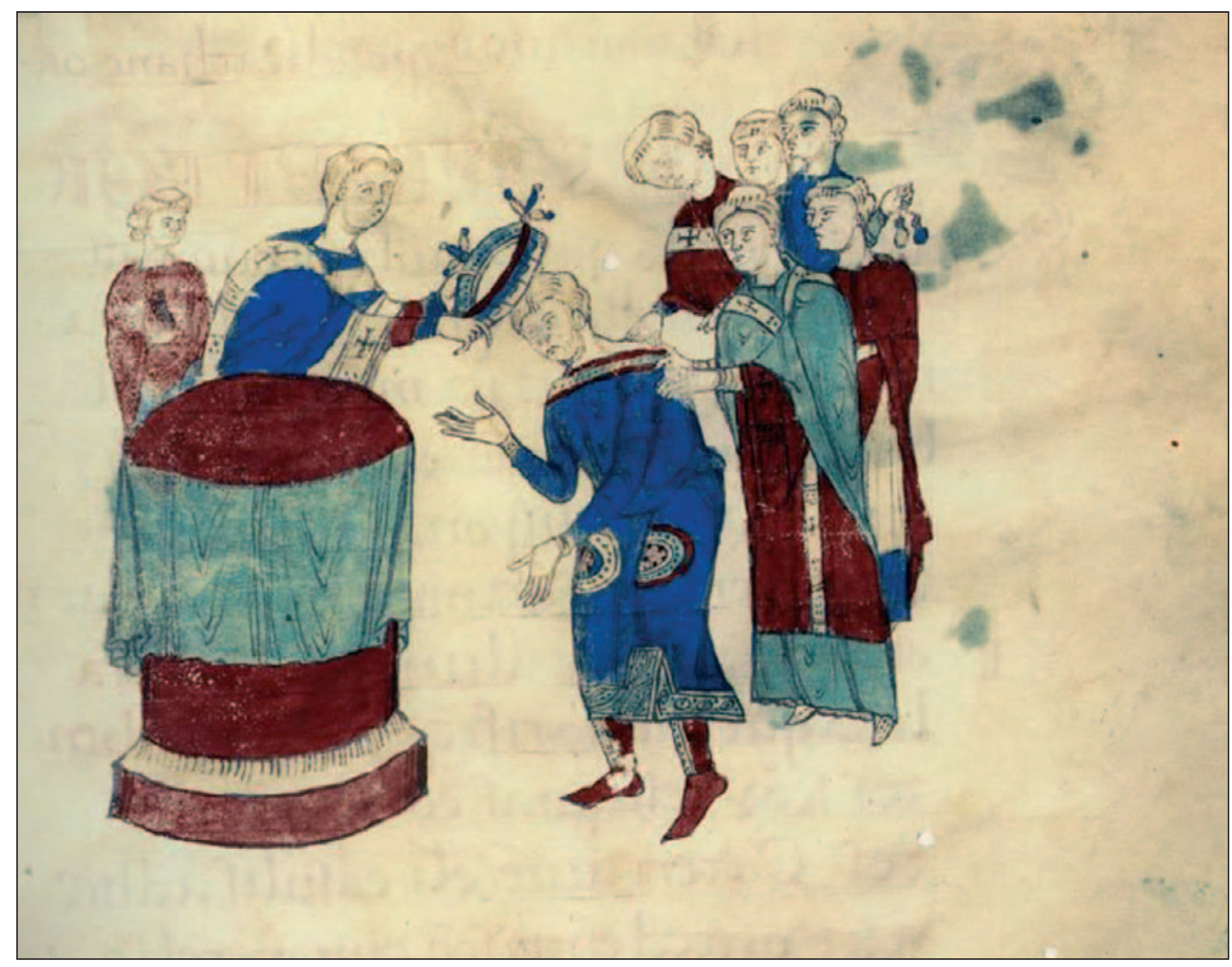

Figura 5

45 Fol. 2. El Códice se conserva en la Biblioteca Capitolare, Ivrea (Mariaux, 2002) 
manera parecida: Evocación de la unción que ya se ha producido mostrando emblemáticamente el cuerno; el rey, ungido tal como demuestra la aureola de la cabeza, ya ha sido vestido y de rodillas recibe la bendición. En este sentido la imagen se refiere únicamente a la unción propiamente dicha, que terminaría con la bendición episcopal y se pasaría después a la coronación.

Para concluir sobre todo lo dicho hasta aquí acerca de la ceremonia de unción/coronación en la tradición hispanogoda, diría que el proceso sería como sigue: 1) la unción se haría sobre la coronilla del monarca y seguramente sobre otras partes del cuerpo; 2) una vez ungido sería vestido con la stola regalis; 3) recibiría entonces la bendición del oficiante principal; 4) a continuación se procedería a la imposición de la corona; 4) por últimose producía la manifestación mayestática del monarca, luciendo la corona y el indumento regio.

El Museo Glencairn (Bryn Athyn, Pensylvania) conserva una cajita de marfil con apliques de latón dorado que considero que se trata de un contenedor de una crismera para una unción regia ${ }^{46}$. Creo que hay argumentos plásticos suficientes para poder catalogar esta obra como hispana y más exactamente en el territorio riojano del siglo XI. Su máximo interés reside en las imágenes representadas. En los dos frentes mayores se reproducen sendos pasajes de la vida del rey Salomón. En uno de ellos vemos la alegría del pueblo por la unción de Salomón en Guijón [Fig. 6]. El tema se recoge en I Reyes (1, 32-45). David ha decidido ungir a Salomón y dispone que Sadoc, sacerdote, Natán, profeta, y Banayas, miembro de la guardia real, conduzcan a su hijo montado en una mula y le bajen a Guijón para ser allí ungido. Una vez en el lugar, "tomando Sadoc, sacerdote, el cuerno de óleo del tabernáculo, ungió a Salomón al son de las trompetas, y gritó a todo el pueblo Viva Salomón rey. Después subió con él todo el pueblo, tocando las flautas y haciendo gran fiesta". La iconografía bíblica hispana cuenta con buenas ilustraciones del tema. La Biblia de San Isidoro del 960 nos muestra a Salomón sobre la mula, regresando de la unción, mientras que su sequito hace sonar las trompetas

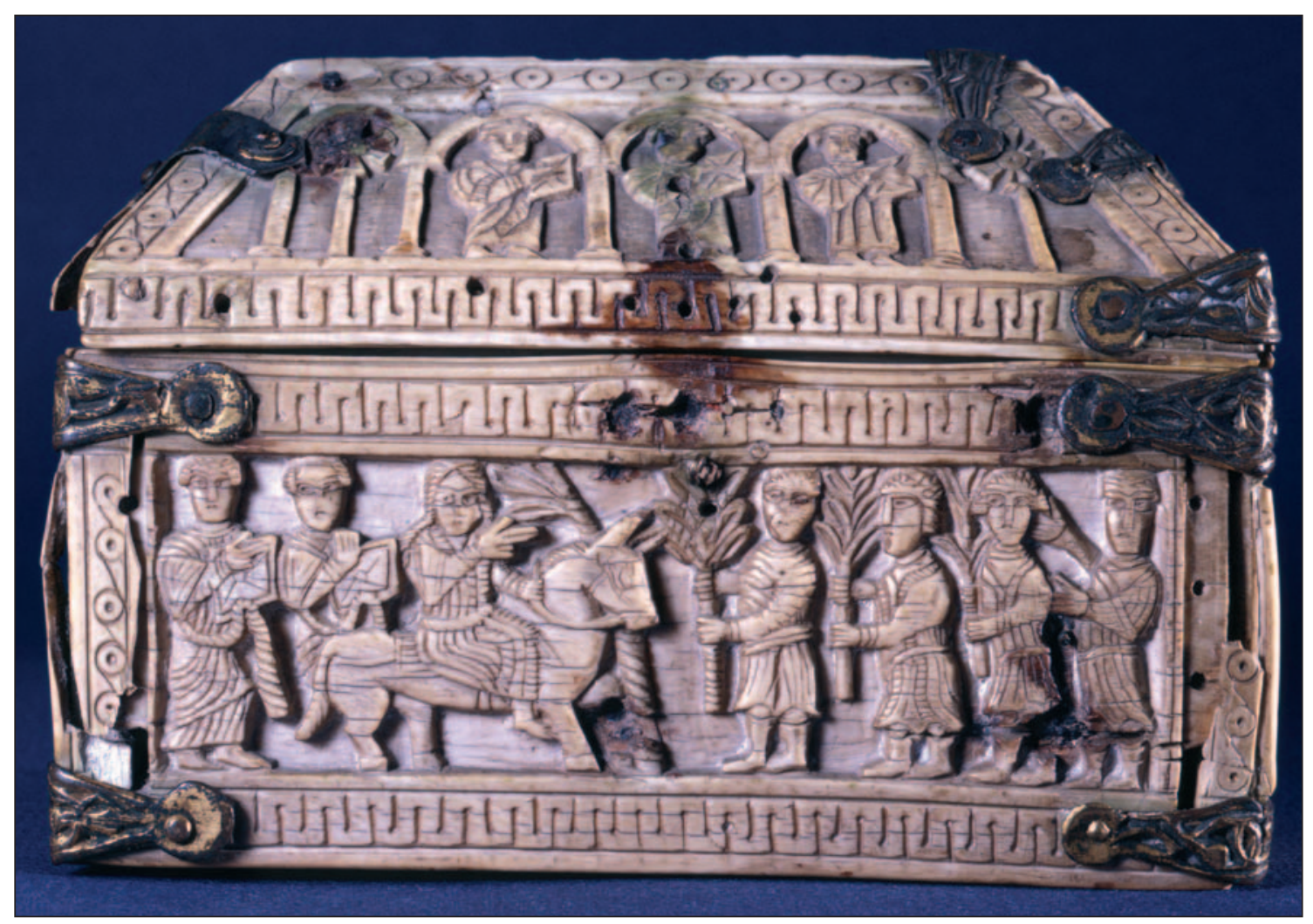

Figura 6

46 Sobre el origen de esta obra y sus características vid. Bango Torviso, 2006. 
y en la ciudad las gentes le reciben también al son de sus bocinas [Fig. 7]. La imagen de la Biblia de San Millán reproduce el mismo tema, pero algo más simplificado [Fig. 8]. El rey jinete sobre la mula, ya ha sido ungido puesto que va tocado con corona, es seguido por un alegre sequito que hace sonar trompetería y aporrear sus tambores. No figura aquí la ciudad. Como se puede comprobar en las imágenes no sólo ha cambiado el lenguaje plástico, el prerrománico en el primer caso, el románico en el segundo, sino que el lenguaje de los símbolos también responde a dos concepciones distintas. El Salomón románico lleva una corona propia de la época y los arreos de su mula son de oro como corresponden a un monarca del siglo XII, el rey de la biblia leonesa lleva un típico halo propio de los ungidos en la tradición hispana y su mula carece de arreos dorados ${ }^{47}$. La escena de nuestra cajita es de una mayor riqueza iconográfica que las imágenes bíblicas pintadas. Posiblemente esto se deba a que las ilustraciones de las biblias no tienen más trascendencia que una figuración rápida que evoque los numerosísimos temas que están descritos en el códice, sin preten- der un mayor detalle. En la caja la imagen representada está dotada de un enorme interés paradigmático, que debe explicar con precisión el trascendente significado del contenido. Se representa también el retorno de Salomón tras la ceremonia de la unción, entendida esta como acabamos de señalar para la biblia leonesa. Figuran los dos celebrantes de pie, el sacerdote Sadoc y el profeta Natán, teniendo un libro en las manos. A continuación Salomón cabalgando la mula, por detrás una palmera. Siguen tres personajes de pie enarbolando palmas en evidente señal de júbilo. Por último, un hombre levanta los brazos como señalando al príncipe. Tiene toda lógica que este sea Banayas, el tercer personaje al que David había encargado la ceremonia de la unción. También se produce un cambio radical con la iconografía tradicional de este tema: el júbilo del pueblo no se expresa con música, sino que levantan palmas. Incluso llama la atención la única palmera representada que adquiere un papel de enorme protagonismo, su estrecha relación con la figura de Salomón todavía incide aún más en su significado. A este respecto debemos recordar las pala-

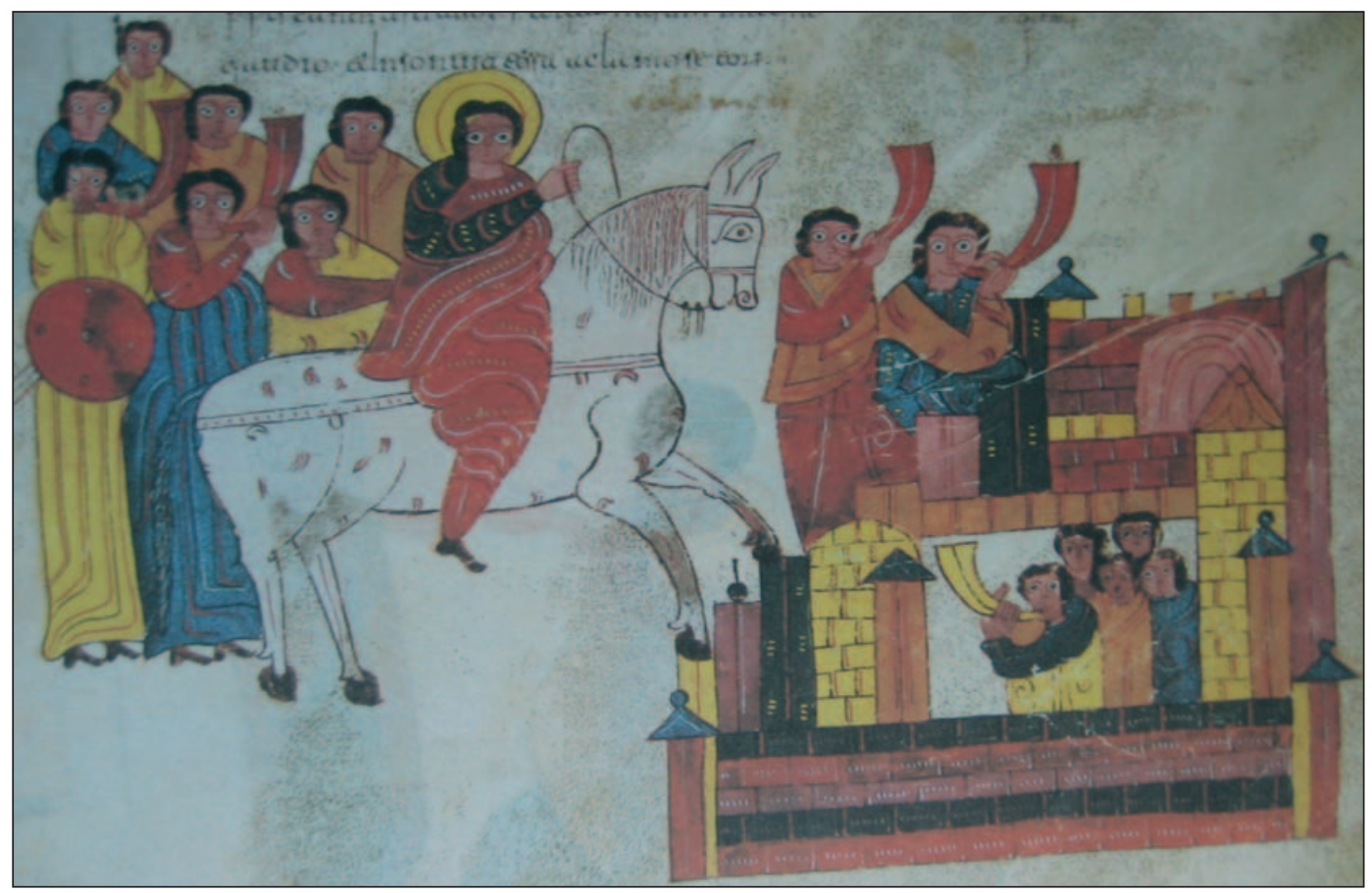

Figura 7

47 Posiblemente, entre las dos imágenes hay dos conceptos distintos, no tanto de representar al monarca, que también, sino del significado de la ceremonia. Mientras que en la biblia leonesa el monarca ha sido simplemente ungido, en la emilianense la ceremonia de la unción también incluía la coronación. 


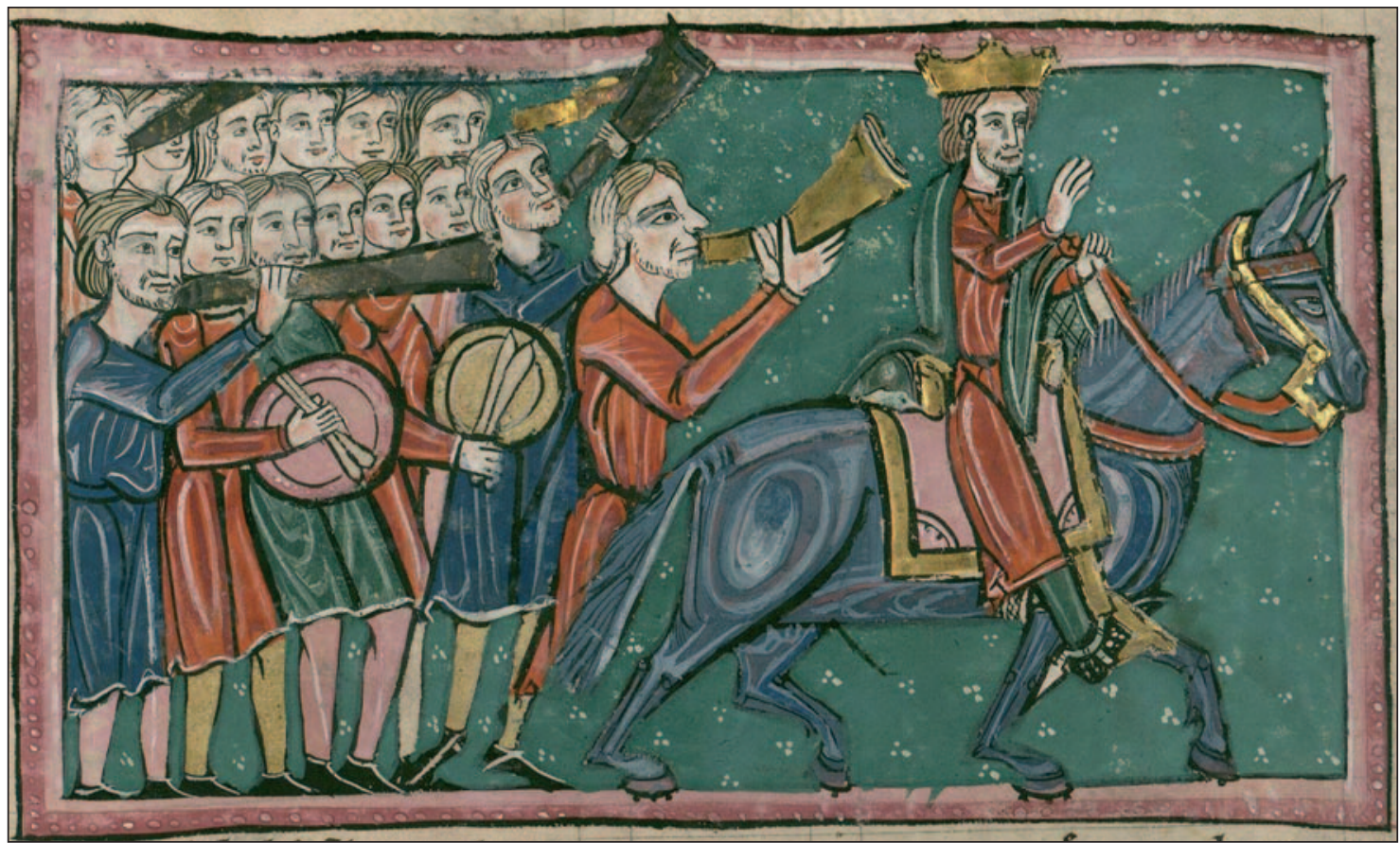

Figura 8

bras del salmista: "El justo florecerá como la palmera; crecerá como cedro en el Líbano" ${ }^{48}$. Sin duda estamos aquí con una imagen que alude directamente a la unción, pero a su vez nos anuncia una de las virtudes que Dios quiere para sus ungidos, el que sea justo.

El ungido en su papel de juez justo crecerá y sus actuaciones adquirirán tanta fama como el lla- mado "juicio de Salomón”. Este tema es el representado en la escena que ocupa el otro flanco largo de la arqueta [Fig. 9]. La gran figura de Salomón aparece sedente en su trono, teniendo dos soldados detrás, mientras que con sus manos nos muestra el acto que está teniendo lugar delante de él. El soldado que ha recibido la orden de matar al niño, le tiene cogido por una pierna y está

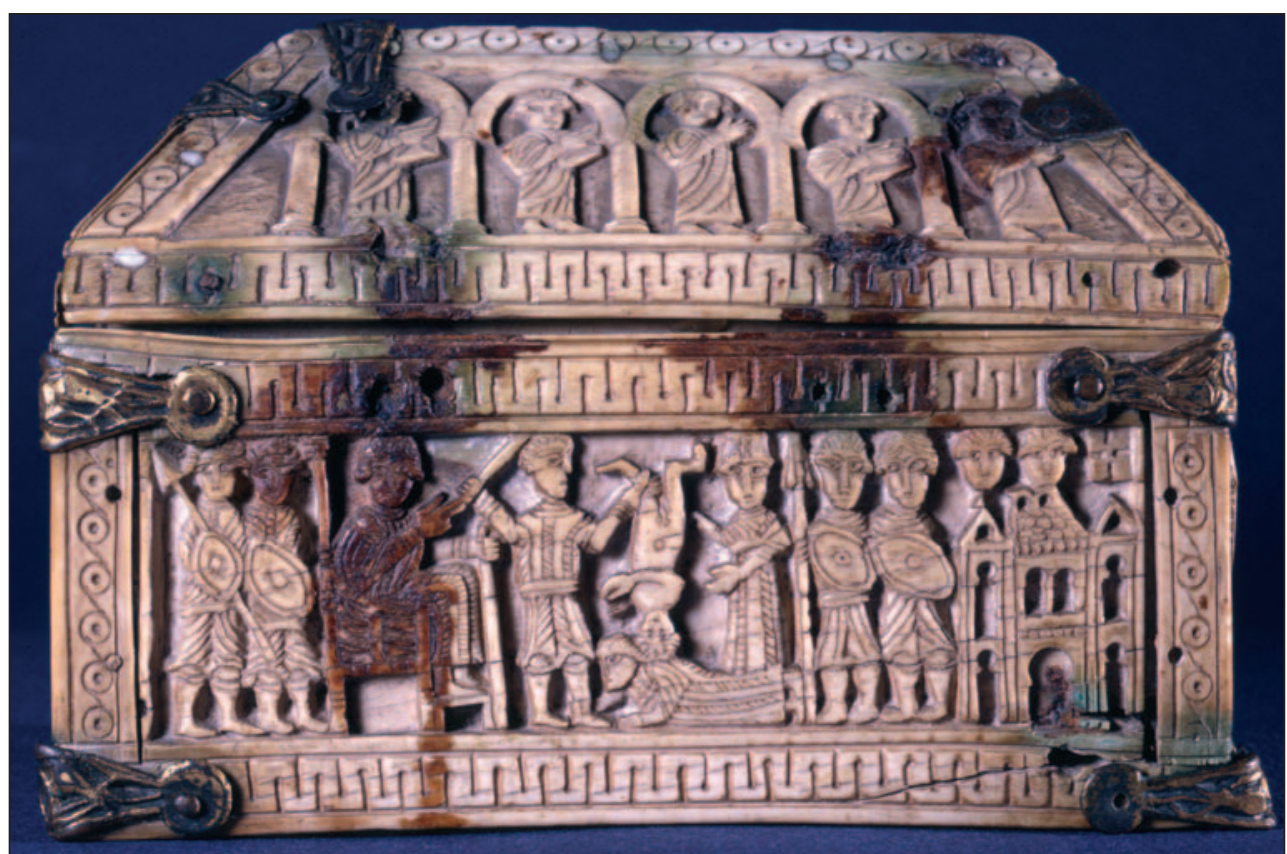

Figura 9

48 Salmos, 92:12-15 
dispuesto a cortarlo en dos partes. La madre verdadera postrada en el suelo, mientras que la otra aparece de pie e impávida. Cierra la composición otra pareja de soldados en perfecta simetría con los anteriores. A continuación figura una arquitectura sobre la que hay dos cabezas humanas. El tipo de arquitectura nos recuerda la convencional que representa una ciudad en la miniatura hispana ${ }^{49}$, mientras que las cabezas no son otra cosa que la representación del pueblo. Esta última imagen corresponde a la ilustración del versículo postrero del texto bíblico que narra el tema: "Todo Israel supo la sentencia que el rey había pronunciado, y todos temieron al rey, viendo que había en él una sabiduría divina para hacer justicia ${ }^{50}$.

En uno de los lados menores figura la imagen de un templo, que en este contexto no hay dificultad para identificarlo con el templo de Salomón [Fig. 10]. La identificación de la cara opuesta no soy capaz de interpretarla satisfactoriamente [Fig. 11]. Un ángel nos muestra a una mujer o a un joven que ocupa el centro de la composición, mientras que, del otro lado, un personaje parece bendecirla con la mano derecha. Si no fuera una mujer, sino un joven el representado podría interpretarse como la elección de David o Salomón, el ángel representaría la voluntad divina y el otro personaje sería el profeta ${ }^{51}$.

La interpretación del conjunto del programa iconográfico responde perfectamente a la teoría de la unción del rey. Tanto el antifonario como el Liber Ordinum reiteran, una y otra vez, la virtud que debe tener y desarrollar el monarca: impartir justicia y ser justo. De las tres lecturas del Commicus, aquí se ha elegido especialmente, además de la referencia a la unción, la correspondiente al Libro de la Sabiduríade Salomón, exactamente en aquellos aspectos donde el monarca reclama a Dios que le conceda sabiduría para juzgar. A su vez Dios le encarga que sea piadoso ofreciéndole sacrificios y especialmente construyendo un templo. En conclusión: la referencia a la unción y a las virtudes del monarca recogidas en el ceremonial de la misma no pueden ser mejor ilustración para un contenedor de unas crismeras destinadas a una unción regia. Aunque los términos justo y piadoso con referencia a un monarca pueden tener semejanzas con la tradición imperial, en las monedas visigodas a partir de Leovigildo responden claramente a las virtudes que, siguiendo los tipos veterotestamentarios, deben adornar a los reyes según los padres de la iglesia de época hispanogoda.

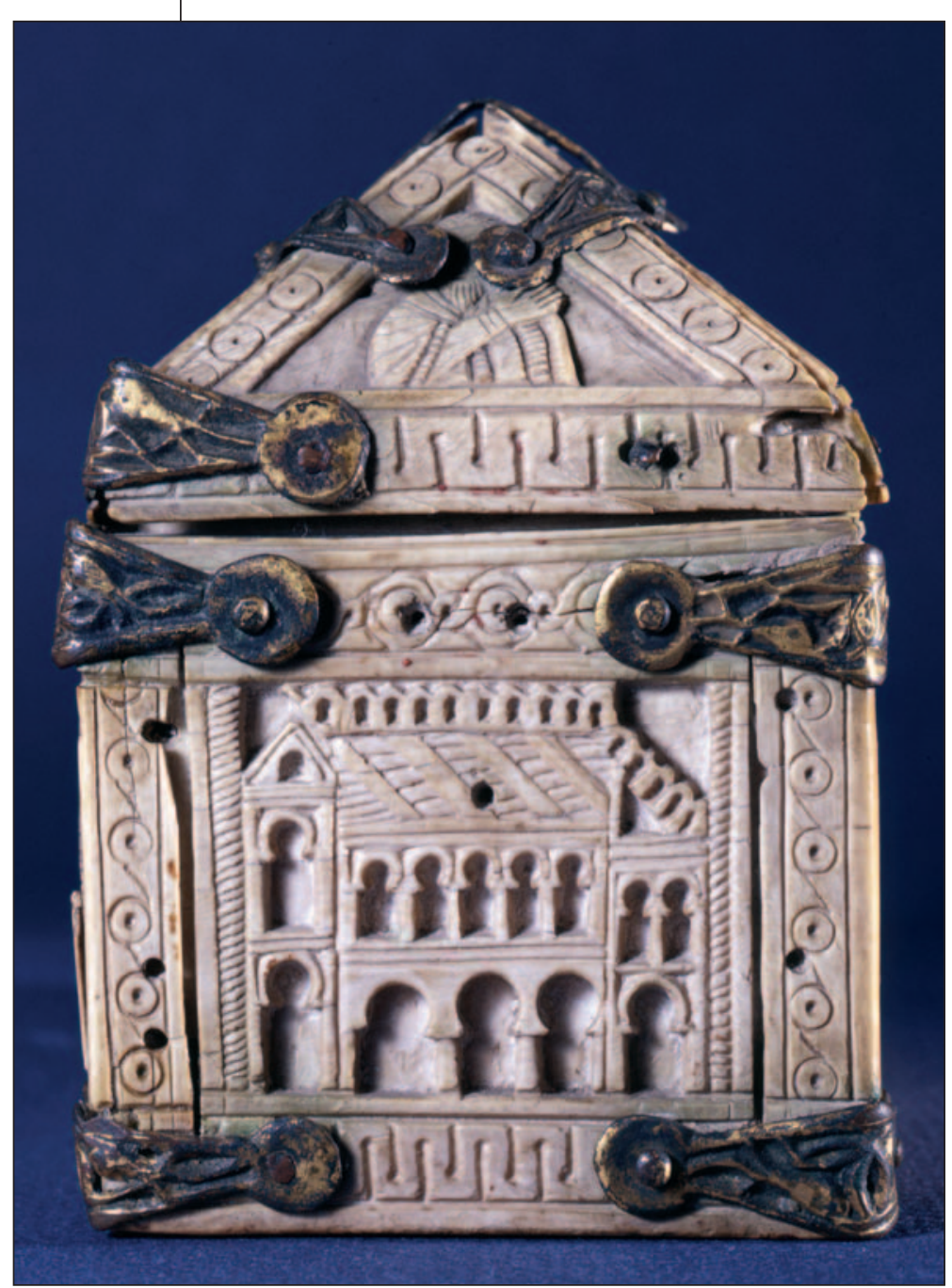

Figura 10
49 Beato de Fernando I, fol. 233v. Babilonia.

50 I Reyes, 3, 28.

51 Por su aspecto parece una mujer, compárese con la imagen de la mujer que está de pie en la escena del juicio. Si fuera así tendríamos que pensar en la reina de Saba, pues su actuación incide en la idea de la sabiduría de Salomón. 


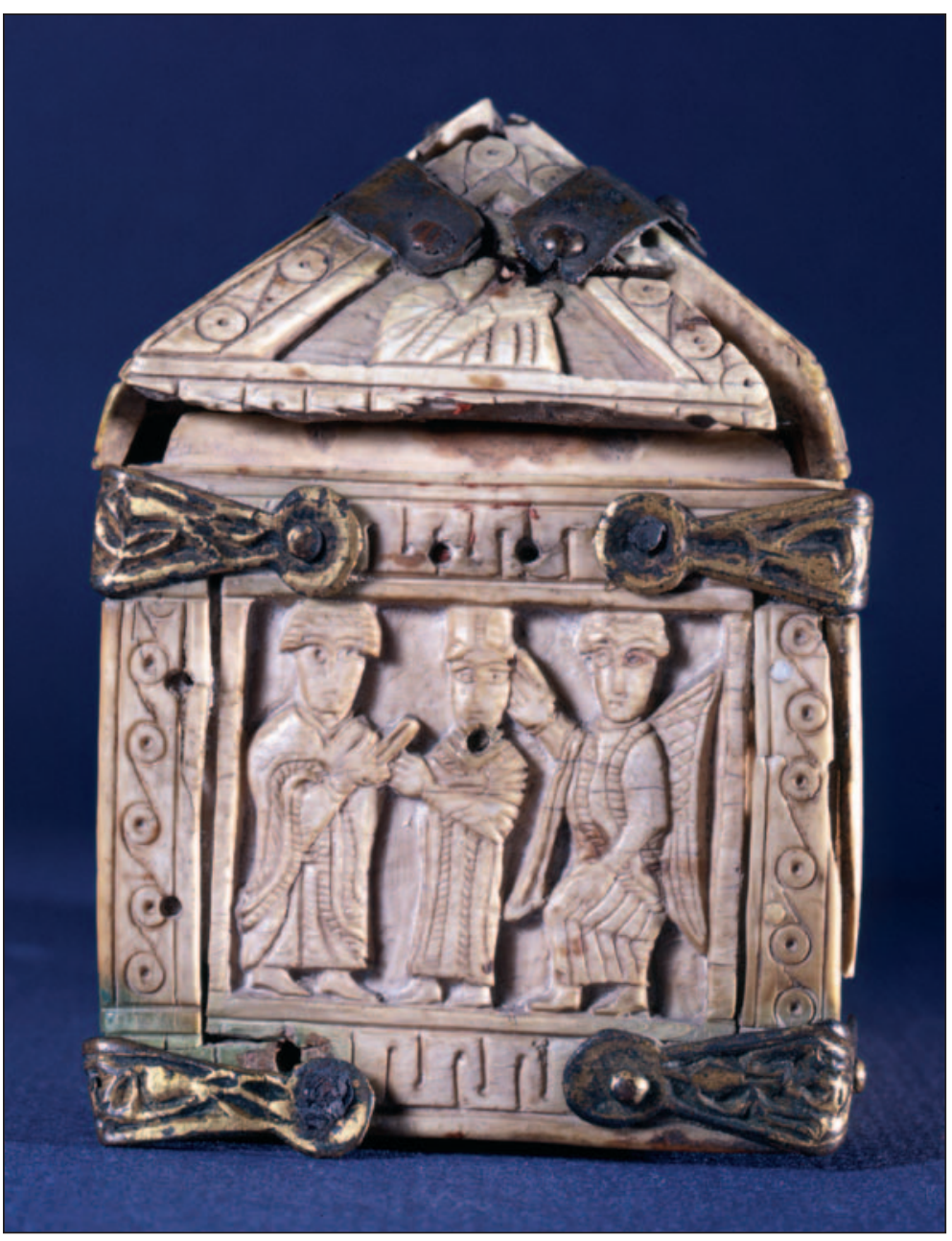

Figura 11

No ha sido mi intención haber tratado aquí de los ragalia de los reyes visigodos y altomedievales. Indirectamente los hemos citado en varias ocasiones. Trono, cetro, espada, corona, diadema y túnica real son tan ampliamente citados por las fuentes de época y contextualizados en diversas circunstancias, que resulta inútil negar su existencia real. Sin embargo es necesario precisar que la ceremonia de la sagrada coronación se reduce a los siguientes aspectos: unción/consagración, túnica real y corona/diadema. Como vemos, se trata de un ritual muy escueto en relación con la serie de regalia que suele ser habitual en este tipo de ceremonia. Cuando el autor de la Silense nos describe los momentos finales de Fernando I, la actuación penitencial del monarca la presenta como un proceso inverso al de la unción/coronación:
"Con voz clara dijo al Señor: Tuya es la potestad, tuyo el reino, Señor; tú estas sobre todos los reyes; bajo tu imperio todos los reinos celestiales y terrestres se someten, y, por tanto, el reino que concedido por ti obtuve $\mathrm{y}$ que recibido goberné por todo el tiempo que plugo a tu libre voluntad, he aquí te lo devuelvo: tan solo ruego porque mi alma, arrancada a la tempestad de este mundo, la recibas en paz. Y esto diciendo, se despojó de la clámide real con que envolvía su cuerpo y depuso la corona alhajada que ceñía su cabeza" 52

Con una cuidada prosa dramático/literaria el autor nos está trasmitiendo las ideas básicas de la ordenación regia. Se trata de un concepto teocrático de la monarquía: Dios ha elegido al rey y le ha concedido el reino para que lo gobernase. Fernando, en los momentos finales de su vida, devuelve el reino recibido y los emblemas que le caracterizaban como rey: la clámide regia y la corona. Estos dos son exactamente los únicos regalia que el monarca habría recibido durante su unción si esta hubiera sido realizada bajo el ritual hispanogodo que hemos reconstruido a partir de los textos litúrgicos de la ordenación. Cuarenta y seis años después, su biznieto, el futuro Alfonso VII, tal como ya hemos señalado, será consagrado por Gelmírez en una ceremonia que introduce cambios sustanciales, especialmente en relación con los regalia. La ceremonia seguirá la siguiente secuencia: unción, entrega de la espada y del cetro, corona/diadema y asiento en el trono (no se contaba con uno regio $\mathrm{y}$, como nos dice la Compostelana, utilizó para ello la sede pontifical). Esta es una fórmula que podríamos considerar fruto del Pontifical Maguncia/Roma. Su práctica por Gelmírez podría explicarse por la introducción del nuevo rito romano.

52 Gómez-Moreno, M., pp. CXXXV - CXXXVI. 


\section{Bibliografía}

\section{BANGO TORVISO, ISIDRO G.}

"El Rey. Benedictus qui venit in nomine Domini", en Maravillas de la España Medieval. Tesoro Sagrado y Monarquía, Junta De Castilla y León 2000 , pp. $23-30$

SUMMA ARTIS. Arte prerrománico hispano. El arte en la España cristiana de los siglos VI al XI, Madrid, 2001

"Crismera", en La Edad de un Reyno, vol. I, Pamplona, 2006

\section{BARROSO, MORIN Y VELÁZQUEZ}

Rafael Barroso Cabrera, Jorge Morín de Pablos, Isabel Velázquez Soriano "La imagen de la realeza en el reino visigodo de Toledo a través de la iconografía y la epigrafía", en Zona Arqueológica, 11, 2008, pp. 488-508.

\section{BESGA MARROQUIN, ARMANDO}

Orígenes hispanogodos del reino de Asturias, Oviedo, 2000

BROU, LOUIS

"Le joyau des AntiphonairesLatines", en Archivos Leoneses, $\mathrm{n}^{\circ} 15$ - 16, 1954, pp. 7 - 114

\section{BROU Y VIVES}

Louis Brou y José Vives, Antifonario visigótico mozárabe de la catedral de León, BarcelonaMadrid, 1959

\section{CANTOROWICZ, E. H.}

Los dos cuerpos del rey, Madrid, 1985 (1957)

\section{CRÓNICAS ASTURIANAS}

Crónicas Asturianas, edic, de Juan Gil Fernández, José Luís Moralejo, y Juan I. Ruíz de la Peña, Universidad de Oviedo, 1985.

\section{DE AYALA MARTÍNEZ, CARLOS}

Sacerdocio y Reino en la España Altomedieval, Madrid, 2008

DÍAZ Y DÍAZ, M.

"Introducción general a las Etimologías" en San

Isidoro de Sevilla, I, pp. 1 - 257

ENRIGHT, MICHAEL J.

Iona, Tara, and Soissons: The origin of the royal anointing ritual, Berlin, 1985

\section{ETIMOLOGÍAS}

San Isidoro de Sevilla, Etimologías, 2 vols. Edic. de José Oroz Reta y Manuel Marcos Casquero, Madrid, 1982

\section{GALVÁN, FERNANDO}

"La representación de la unción regia en el antifonario de la Catedral de León", en Archivos Leoneses, $\mathrm{n}^{\circ} 97$ - 98, 1995, pp. 135 - 146,

\section{GARCÍA DE CASTRO, CÉSAR}

"Notas sobre teología política en el Reino de Asturias: La inscripción del altar de Santa María de Naranco (Oviedo) y el testamento de Alfonso II", en Arqueología y territorio medieval 10.1, 2003, pp. 137 - 170

\section{GÓMEZ-MORENO, M.}

Introducción a la Historia Silense, Madrid, 1921

\section{GÓMEZ MORENO, Mª ELENA}

"Las miniaturas del antifonario de la Catedral de León”, en Archivos Leoneses, no 15 - 16, 1954, pp. $303-317$

\section{HEN, YITZHAK}

"Rois et liturgie en Gaule franque " en Cahiers de Civilization Médievale, 50 (2007), pp. 33 - 41

\section{HISTORIA COMPOSTELANA}

Historia Compostelana, edic. de Emma Falque Rey, Madrid, 1994

\section{HISTORIA SILENSE}

Historia Silense, edic. Justo Pérez de Urbel y Atilano González Ruíz Zorrilla, Madrid, 1959

\section{JACOBSON, PAUL A.}

"Sicut Samhuel unxit David: Early carolingian royal anoitings reconsidered", en Medieval Liturgy . A book of Essays, ed. Lizette LarsonMiller, Nueva York y Londres, 1997

\section{LAS HISTORIAS DE LOS GODOS}

Las historias de los godos, vándalos y suevos de Isidoro de Sevilla, ed. Cristóbal Rodríguez Alonso, León, 1985

\section{LIBER COMMICUS}

Fray Justo Pérez de Urbel y Atilano Ruíz Zorilla, Liber Commicus, 2 vols. Madrid, 1950

\section{LIBER ORDINUM EPISCOPAL}

Liber Ordinum episcopal, ed. José Janini, Abadía de Silos, 1991

\section{LINEHAN, P.}

History and the historians of Medieval Spain, Oxford, 1993

\section{MARIAUX, PIERRE-ALAIN}

Warmond D'Ivree Et Ses Images: Politique Et Creation Iconographique Autour De L'an Mil, Berna, 2002 


\section{SÁNCHEZ ALBORNOZ, CLAUDIO}

"La Ordinatio Principis en la España goda y postvisigoda", en Viejos y nuevos estudios sobre las instituciones medievales españolas, II, Madrid, 1976, pp. 1173 - 1207

SANCTI IULIANI TOLETANAE SEDIS EPISCOPI OPERA

Sancti Iuliani Toletanae Sedis Episcopi Opera, CXV, Pars I, Typographi Brepols, Bélgica, MCMLXXVI

SILVA, SOLEDAD

La Miniatura en el Monasterio de San Millán de la Cogolla, Logroño, 1999

\section{VIVES}

José Vives ed. Concilios Visigóticos e hispanoromanos, Barcelona-Madrid, 1963

\section{YARZA LUACES, JOAQUÍN}

"Las miniaturas del Antifonario de León", en el Bol. del Seminario de Estudios de Arte y Arqueología de Valladolid, 1976, pp. 181 - 205 


\section{Normas para la redacción de originales}

1. Los originales deberán estar mecanografiados en formato DIN A-4 con un máximo de 34-36 líneas de 75 caracteres por página. No se podrán aceptar originales con mayor densidad de caracteres por página.

2. Junto con el texto mecanografiado se incluirá una copia del mismo en soporte magnético en formato Wordperfect, Word, o RTF. Se evitará el uso de tabuladores y retornos manuales salvo en los puntos y aparte. En la etiqueta se indicará el título del trabajo, autor/es y formato. Se procurará que el texto venga libre de erratas para facilitar la corrección de pruebas al Consejo de Redacción, ya que no se remitirán pruebas de imprenta a los autores por razones de coste.

3. Los artículos deberán venir acompañados de un resumen en la propia lengua del trabajo y en otra lengua de difusión internacional (español, inglés, francés, italiano, alemán). Los resúmenes tendrán una extensión máxima de 15 líneas de 75 espacios cada una.

4. Los artículos vendrán acompañados por un máximo de seis palabras clave que describan una rápida localización en una búsqueda informatizada por temática, metodología, cronología y localización.

5. La extensión máxima de los trabajos será de 40 páginas de texto y hasta 15 ilustraciones (dibujos o fotografías) si ocupan el evilante de la caja de CUPAUAM (24,5 x 16,5 $\mathrm{cm}$.), o hasta 20 ilustraciones si son de menor tamaño.

6. Todas las ilustraciones vendrán numeradas correlativamente, independientemente de que se trate de fotografía, dibujos a línea, gráficos o tablas. Los dibujos incluirán esca- la gráfica y se procurará que se adapten en sus proporciones a la caja de CuPAUAM $(24,5 \times 16,5 \mathrm{~cm}$.) -caja completa, media caja horizontal, o cuarto de caja-. Para el grosor de las líneas y densidad de sombras de los dibujos se tendrán en cuenta los porcentajes de reducción necesarios.

No se pueden realizar reproducciones a color. Las tablas de valores o datos vendrán integradas en el procesador de texto, en página aparte, con márgenes adecuados y numeradas correlativamente con el resto de las figuras. No se emplearán los términos "Tabla", "Cuadro", "Mapa", etc. En el caso de que tal cosa no sea posible, vendrán impresas o escritas a máquina electrónica y sin erratas, para que puedan ser reproducidas como una figura.

7. Se acompañará una hoja aparte con los pies de las figuras. Si proceden de otras publicaciones se citará la fuente. Es responsabilidad de los autores asegurar la cesión del copyright de las ilustraciones en caso necesario.

8. En el encabezamiento del trabajo, bajo el título y antes que el resumen, se indicará el nombre del/los autor/es, así como el centro o centros en que trabajen. El remitente indicará en hoja aparte los mismos datos, junto con su dirección, teléfono y fecha de envío del trabajo.

9. Se podrá usar el sistema tradicional de citas o el americano, o uno mixto, a elección del autor.

9.1. En notas cortas (referencia a un trabajo), se pondrá el nombre de éste en caracteres normales -no en mayúsculas-, seguido del año de edición de la obra, 
página o páginas y figura o figuras, todo ello separado por comas. Estas citas figurarán en el texto, entre paréntesis, y no al final ni al pie de la página.

9.2. Las notas largas deberán ir al final del texto, con las referencias bibliográficas igual que en 9.1.

9.3. Al final del artículo se incluirá la lista de la bibliografía citada, ordenada alfabéticamente según el primer apellido de los autores. Si un autor tienes varias obras citadas, se ordenarán de más antigua a más reciente. Si hay varias obras de un autor en un mismo año, se distinguirán con las letras minúsculas ( $a, b, c$, etc.) que se incluirán también en las referencias de 9.1 y 9.2 .

9.4. Cuando se trate de un libro se citará por este orden: apellidos e inicial del nombre del autor, fecha de edición entre paréntesis, dos puntos, título de la obra y lugar de edición.

9.5. Cuando se trate de un artículo de revista: autor, año, título del artículo entre comillas, nombre de la revista en cursiva, tomo o número, y páginas.

9.6. En colaboraciones en libros colectivos: autor, año, título de la colaboración, título del libro (con el nombre del editor o coordinador en su caso, tomo y páginas, lugar de edición).

9.7. El nombre de los autores irá en letras mayúsculas en la Bibliografía final (no así en el cuerpo del texto, véase 9.1.). El título de los libros y de las revistas, subrayado o en cursiva; el de los artículos de revistas y colaboraciones, entre comillas.
9.8. Si se citan abreviadamente títulos de revistas o series, se emplearán las abreviaturas de CUPAUAM para revistas españolas, y algún sistema reconocido internacionalmente (L'Année Philogique, Archáologische Bibliographie, American Journal of Archaeology) para las extranjeras.

\section{Ejemplos de citas:}

9.1. (Abad Casal, 1991:185).

9.2. ... recientemente. Abad Casal (1991:185) indica que...

9.4. GARCÍA Y BELLIDO, A. (1949): Esculturas romanas de España y Portugal. Madrid.

9.5. ABAD CASAL, L. (1983): "Un conjunto de materiales de la Serreta de Alcoy". Lucentum 2, 173-197.

9.6. BELTRÁN LLORIS, M. (1987): "La España celtibérica: la segunda Edad del Hierro en el Valle del Ebro". Historia General de España y América, 1.2, 255-293. Madrid.

10. Los artículos serán revisados por al menos dos evaluadores del Consejo Consultivo y del Consejo Asesor Externo.

11. El Consejo de Redacción se reserva el derecho de devolver los originales que no se correspondan con la línea de la Revista, o que no cumplan estas normas de redacción. El Consejo asesor, a través de su sistema de evaluación, podrá asimismo sugerir las modificaciones que estime oportunas a los originales aceptados. 

